\title{
Vertical diversity of bacteria in an oxygen-stratified humic lake, evaluated using DNA and phospholipid analyses
}

\author{
Sami Taipale ${ }^{1,2}$, Roger I. Jones ${ }^{2}$, Marja Tiirola ${ }^{2, *}$ \\ ${ }^{1}$ University of Washington, Civil and Environmental Engineering, Box 352700, 201 More Hall, Seattle, Washington 98195, USA \\ ${ }^{2}$ Department of Biological and Environmental Science, PO Box 35, 40014 University of Jyväskylä, Finland
}

\begin{abstract}
Microbes play a particularly important role in the food web in lakes with high dissolved organic carbon content. The bacterial community of a polyhumic lake, Mekkojärvi, was studied using DNA techniques and phospholipid fatty acid (PLFA) analysis during the mid-summer period of water column stratification. According to the 16S rRNA gene clone libraries and length heterogeneity analysis (LH-PCR), heterotrophic bacteria dominated only in the oxic epilimnion, in which various Actinobacteria (mostly cluster acI-B) and Betaproteobacteria (especially Polynucleobacter subcluster PnecC) were common. Sequences assigned to heterotrophic, methylotrophic, photoautotrophic, and chemoautotrophic genera were all abundant in the oxic-anoxic boundary layer. Methylobacter and Methylophilus were dominant genera among methylotrophic bacteria. Sequences assigned to the photoautotrophic green sulfur bacterium Chlorobium sp. dominated in the anoxic water column, in which the microbial PLFA biomass was 6 times higher than in the oxic surface layer. All PLFAprofiles were dominated by 16 monounsaturated fatty acids typical of Gram-negative bacteria, whereas isoand anteiso-branched PLFAs typical of Actinobacteria were present only in minor proportions. The high biomass of the potentially autotrophic meta- and hypolimnetic bacteria may form an important carbon source for the whole lake after spring and autumn overturns; thus, the role of these bacteria in the seasonal energy mobilization deserves more study in oxygen-stratified humic lakes and ponds.
\end{abstract}

KEY WORDS: Bacterial diversity · Freshwater · Anaerobic ' Chlorobium ' Polynucleobacter Methanotrophic 'Autotrophic bacteria

Resale or republication not permitted without written consent of the publisher

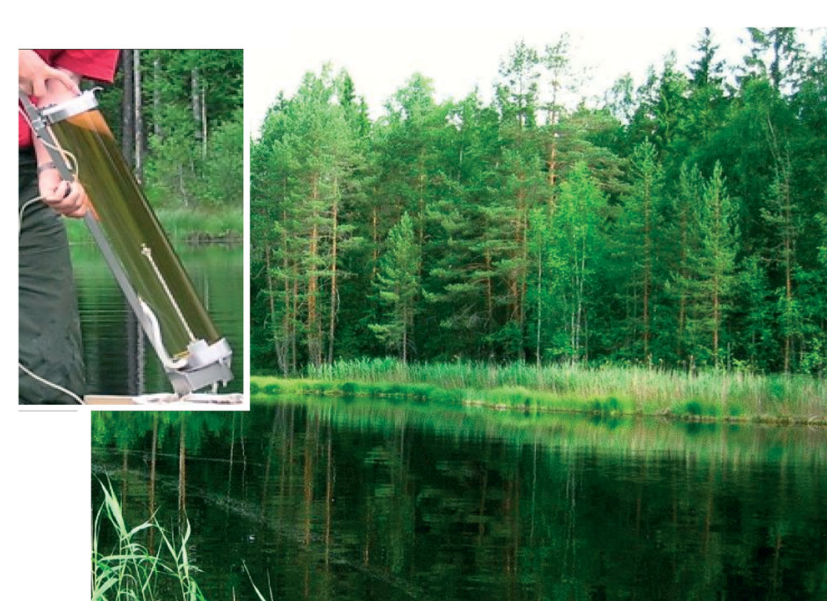

Mekkojärvi, in southern Finland, is one of countless small, humic lakes around the boreal zone; inset: sampling the brown water rich in DOC.

Photos: Sami Taipale

\section{INTRODUCTION}

Microbial foodwebs of humic (dystrophic) lakes receive large amounts of allochthonous carbon from terrestrial sources, and thus terrestrial carbon can contribute to the carbon pathway (Tranvik 1989, Moran \& Hodson 1990). Recent whole-lake studies (Carpenter et al. 2005, Taipale et al. 2008) have revealed that terrestrial organic carbon mediated by bacteria indeed plays a crucial role in the whole foodweb of humic lakes. These studies confirm that bacteria not only decompose terrestrial carbon, but also assimilate a large part and transmit it to higher trophic levels; in some cases, almost all zooplankton carbon demand can be satisfied by microbial sources (Taipale et al. 2007, 2008). 
Boreal humic lakes are usually steeply stratified in summer with respect to temperature and oxygen. In sheltered lakes and ponds, the anoxic hypolimnion can be many times thicker than the oxic epilimnion, and thus the anoxic decomposition of dissolved organic carbon (DOC), including allochthonous DOC, can have an important role in the carbon cycle. Methanogenesis by Archaea usually dominates anaerobic carbon mineralization in anoxic freshwaters (Canfield et al. 2005), providing both a carbon and energy source for methane-oxidizing bacteria (MOB, methanotrophs) in the water column (Sundh et al. 2005). In addition to methane, hydrogen sulfide $\left(\mathrm{H}_{2} \mathrm{~S}\right)$ and reduced iron $\left(\mathrm{Fe}^{2+}\right)$ are formed under anoxic conditions. These reduced elements are oxidized by different microorganisms, like chemolithoautotrophic bacteria (e.g. Gallionella sp.) and photolithoautotrophic green sulfur bacteria (GSB, e.g. Chlorobium sp.; Heising et al. 1999, Hadas et al. 2001). The species diversity and ecological significance of responsible MOB and chemolithoautotrophic bacteria is of special interest in humic lakes, where the strong light attenuation can severely restrict photoautotrophic production. In view of this wide range of available substrates and environmental heterogeneity in humic lakes, their bacterial communities might be particularly diverse.

The main bacterial clusters specific for freshwater ecosystems have been revealed by $16 \mathrm{~S}$ rRNA gene sequencing (Glöckner et al. 2000, Zwart et al. 2002). Several studies have shown that the bacterial community composition (BCC) of surface waters of humic lakes is often dominated by Actinobacteria and particularly by Betaproteobacteria (Glöckner et al. 2000, Burkert et al. 2003, Eiler et al. 2003, Grossart et al. 2008, Percent et al. 2008), but the vertical diversity of the BCC in humic lakes with oxygen stratification remains largely unstudied. Furthermore, 16S rRNA gene libraries cannot alone reveal the abundance of different bacterial groups, and thus 16S rRNA gene identification must be related to quantitative information. Phospholipid fatty acid (PLFA) analysis has been used for characterization and quantification of the microbial community structure in various terrestrial and aquatic systems (White et al. 1979, Mancuso et al. 1990). Because phospholipids are readily metabolized and are thus relatively short-lived after the death of the cell, they are considered as quantitative biomarkers for living organisms (White et al. 1979). However, when using PLFA profiles of field samples, microbial groups can only be crudely separated, e.g. as Gram-negative bacteria, Gram-positive bacteria, and phytoplankton. By combining PLFA profiles with DNA analyses, a more comprehensive picture can be achieved, and the biomasses of different taxonomic groups can be estimated.
The aim of this study was to investigate the vertical distribution of bacteria in the water column of a humic lake with high DOC content by combining DNA and PLFA techniques. Four 16S rRNA gene libraries with altogether over 400 sequences were analyzed from the oxic (epilimnion) and the anoxic (hypolimnion) water layers, as well as from the anoxic-oxic boundary layer (metalimnion) during summer stratification. Sequence data were combined with the information on closest bacterial genera to predict potential functions of bacteria operating in the different water layers, such as heterotrophy, photoautotrophy, chemoautotrophy, and methylotrophy. Although this classification is only tentative, it provides preliminary insights into the possible processes fuelling the carbon cycle in an oxygen-stratified lake ecosystem. Sequence data were linked with length heterogeneity analysis of PCR-amplified 16S rRNA genes (LH-PCR; Suzuki et al. 1998) and PLFA analysis to identify biomarkers that could be useful for characterization of microbial communities in high DOC content lakes and to estimate the overall composition of bacterial biomass.

\section{MATERIALS AND METHODS}

Study site. Mekkojärvi $\left(61^{\circ} 13^{\prime} \mathrm{N}, 25^{\circ} 8^{\prime} \mathrm{E}\right)$ is located in the Evo forest area in southern Finland. The lake is small (area: $0.35 \mathrm{ha}$ ), shallow (mean depth: $3 \mathrm{~m}$ ), and receives a high loading of terrestrial carbon from the surrounding catchment area. The lake water is dark

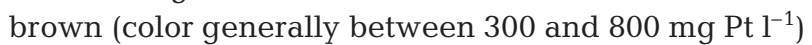
and naturally acidic (pH generally from 4 to 6 ). During the study period, the water color was $411 \pm 50$ and $442 \pm 24 \mathrm{mg} \mathrm{Pt}^{-1}$ in the 0 to 0.6 and 0.6 to $3 \mathrm{~m}$ water layers, respectively, and $\mathrm{pH}$ varied between 5.8 and 6.1 in the whole water column. All means are given with \pm SD. Dissolved inorganic carbon concentration varied from $3.5 \pm 0.8$ to $14.0 \pm 0.8 \mathrm{mg} \mathrm{C}^{-1}$ in the 0 to 0.6 and 0.6 to $3 \mathrm{~m}$ water layers, respectively. More detailed physical and chemical properties of the lake were presented by Kuuppo-Leinikki \& Salonen (1992). After ice-break, the surface water warms rapidly, resulting in steep temperature, oxygen, and nutrient gradients. Spring mixing is often incomplete, but autumn overturn happens regularly. Greater bacterial density has been measured in the oxic-anoxic boundary zone of the metalimnion (20 to $45 \times 10^{6} \mathrm{cells} \mathrm{ml}^{-1}$ )

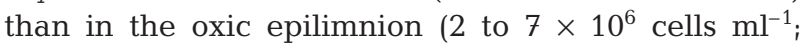
Arvola et al. 1992). The high concentration of bacteriochlorophyll $d$ in the hypolimnion reflects a high density of photosynthethic bacteria, especially during spring and summer at 1.8 to $3.0 \mathrm{~m}$ from where the highest bacteriochlorophyll $d$ concentration $(>200 \mu \mathrm{g}$ 
$\mathrm{l}^{-1}$ ) was measured (Taipale et al. 2008). Methane concentration is highest at 1.8 to $3.0 \mathrm{~m}$, where it is between 100 and $150 \mu \mathrm{mol} \mathrm{l} \mathrm{l}^{-1}$ throughout the open water season. Methane oxidation rate is highest at the depth of 0 to $1.2 \mathrm{~m}$ throughout all seasons, although during autumnal mixing the methane-oxidation rate is high in the whole water column (Taipale et al. 2008).

Sampling procedure. Samples were collected for PLFA analysis and LH-PCR on 11 and 25 July and 1 August, and for 16S rRNA gene sequencing and cloning on 1 August during summer stratification in 2005. Water samples were taken from 4 different layers -0 to $0.6 \mathrm{~m}$ (oxic), 0.6 to $1.2 \mathrm{~m}$ (oxic-anoxic boundary layer), 1.2 to $1.8 \mathrm{~m}$ (anoxic), and 1.8 to $3.0 \mathrm{~m}$ (anoxic) - using a Limnos tube sampler (height $60 \mathrm{~cm}$, volume $4.25 \mathrm{l}$ ). Water was filtered through a $100 \mu \mathrm{m}$ mesh net in the field, and in the laboratory 1.05 to $3.35 \mathrm{l}$ of lake water from each layer were filtered through Whatman GF/F filters for PLFA analysis. About $50 \mathrm{ml}$ of lake water were filtered through a Filtropur acetylacetate filter unit $(0.2 \mu \mathrm{m}$ pore size; Sarstedt) for the DNA analyses. Water temperature and oxygen concentration were measured in situ with a YSI 550A combined temperature and dissolved oxygen meter (Yellow Springs Instruments) and redox potential with a WTW Multiline P3 pH/ conductivity meter equipped with a Schott redoxcombination electrode at $0.5 \mathrm{~m}$ intervals from surface to bottom. The accuracy was $\pm 0.3 \mathrm{mg} \mathrm{O}_{2} \mathrm{l}^{-1}$ for oxygen and $\pm 0.3^{\circ} \mathrm{C}$ for temperature measurements. Ammonium, iron (total concentration by atomic absorption spectrometry), and sulfate were analyzed from each $60 \mathrm{~cm}$ water layer on 25 July using the validated routine methods of the Finnish Standard Association (www.sfs.fi/en/). Methane samples (30 $\mathrm{ml}$ ) were collected in $60 \mathrm{ml}$ polypropylene syringes directly from the Limnos tube sampler and analyzed as described by Taipale et al. (2007).

Cell counts, particulate organic carbon, and DOC. Prokaryotic cell numbers and volumes were determined from acriflavine-stained (Bergström et al. 1986) samples using epifluorescence microscopy and AnalySIS 3.1 Soft Imaging System (www.soft-imaging.net). The total bacterial cell volume was converted to carbon using a factor of $0.36 \mathrm{pg} \mathrm{C} \mathrm{mm}^{-3}$ (Tulonen 1993). Particulate organic carbon (POC) was measured from samples filtered on pre-ignited glass-fiber filters (Whatman GF/F) according to Salonen (1979), and DOC was measured from the filtrate using a Shimadzu total organic carbon analyzer TOC-5000A.

DNA extraction. The DNA extraction procedure was modified from protocols described by Wilson (1990) and Griffiths et al. (2000). Briefly, acetylacetate filters were opened and dissolved in $400 \mu$ l of phenol-chloroform-isoamylalcohol (25:24:1), after which the samples were homogenized with $0.4 \mathrm{~g}$ of $0.1 \mathrm{~mm}$ diameter glass beads and $400 \mu \mathrm{l}$ of TE buffer (10 mM Tris [pH 8.0], 1 mM EDTA) in microcentrifuge tubes in a FastPrep bead-milling instrument (speed 5.5 for $30 \mathrm{~s}$ ). The samples were then re-extracted with chloroform-isoamylalcohol (24:1), precipitated with ethanol, and dissolved in $100 \mu \mathrm{l}$ of sterile water.

LH-PCR analysis and sequencing. 16S rRNA genespecific PCR was performed as described by Tiirola et al. (2003), except that the polymerase was provided from Biotools and the reaction mixture included $1 \mathrm{mg}$ $\mathrm{ml}^{-1}$ bovine serum albumin. The broad-range bacterial PCR primers were forward primer 27F (5'-AGA GTT TGA TCM TGG CTC AG-3'; Lane 1991) and IRD700 labeled reverse primer PRUN518r (5'-ATT ACC GCG GCT GCT GG-3'; Muyzer et al. 1993), which amplify naturally varying 465 to 565 bp long fragments of the 16S rRNA gene (Tiirola et al. 2003) corresponding the Escherichia coli region 8-534. LHPCR gel electrophoresis was performed with an automated LI-COR 4200 sequencer (LI-COR BioTech) using $6 \%$ Long Ranger denaturing polyacrylamide gel (FMC Bioproducts). The molecular size marker consisted of LH-PCR products of known sequence lengths. The data were analyzed using QuantityOne software (Bio-Rad Laboratories). Cloning of the same 16S rRNA gene PCR products (without IRD-labeling) was performed using the TOPO TA Cloning Kit for Sequencing (Invitrogen) according to the manufacturer's instructions. The sequencing of the clone library was performed using the BigDye Terminator v3.1 Cycle Sequencing Kit (Applied Biosystems) and vector primers T7 and T3. The samples were run in the ABI3100 capillary sequencing instrument (Applied Biosystems). Exact lengths (bp) of the inserts were calculated from the sequence data, and the information was used to link the phylogenetic classification of the sequences to the corresponding LH-PCR peaks.

Sequence analysis. DNA sequences were edited using Contig Express software (Invitrogen) and clustered to operational taxonomic units (OTUs) at 95 $\left(\mathrm{OTU}_{0.95}\right)$ or $99 \%\left(\mathrm{OTU}_{0.99}\right)$ sequence similarity level using the CD-HIT program (www.bioinformatics.org/ cd-hit/). Sequences ( 450 bp in length) were compared to those in databases using BLAST software and the Ribosomal Database Project II programs Seqmatch and Classifier (http://rdp.cme.msu.edu). ClustalX was used for sequence alignment and for constructing a neighbor-joining tree for selected Mekkojärvi clones representing major phylotypes $\left(\mathrm{OTU}_{0.95}\right.$ having more than 2 similar clones). The alignment was corrected by hand-editing using the program Bioedit (www.mbio. ncsu.edu). Nucleotide sites with gaps in any of the sequences were excluded from the analysis, and the 
final tree was based on the analysis of 367 aligned positions. In addition, actinobacterial sequences were compared to freshwater clusters presented by Glöckner et al. (2000), Urbach et al. (2001), Zwart et al. (2002), and Warnecke et al. (2004). Betaproteobacterial sequences were compared to the clustering of Zwart et al. (2002), except Polynucleobacter sequences, which were compared in more detail to the $4 P$. necessarius clusters presented by Hahn (2003). Chlorobi sequences were compared to the sequences of the closest type strains of the genera Chlorobium and Chlorobaculum (Imhoff 2003). Confidence values for the groupings of the trees were derived by bootstrap analysis with 100 iterations. The sequence data are deposited in the EMBL database under accession numbers AM949036 to AM949471.

Functional classification of bacterial sequences. Potential functions of bacterial groups in different water layers of Mekkojärvi were estimated using the 16S rRNA gene sequence results. All bacterial sequences were assigned to distinct functional groups according to the primary carbon and energy source of the closest matching cultivated and classified organisms, following descriptions of distinct species by Balows et al. (1992). Bacteria were classified as phototrophic or chemotrophic according to their energy source. All bacteria that use an organic carbon source were considered heterotrophic. Methylotrophic bacteria were separated from autotrophic bacteria to a group including $\mathrm{MOB}$ and other bacteria using $\mathrm{C}-1$ compounds. Bacteria that have an anaerobic respiration pathway were classified as anaerobic bacteria. Sequences that did not have matches to cultivated organisms but matched sequences of the thus far uncultivated candidate phyla TM7 or OP11 were classified as chemoheterotrophic.

Phospholipid analysis. Immediately after filtration, Whatman GF/F filters were placed in extraction tubes containing $28.5 \mathrm{ml}$ of chloroform-methanol-50 mM phosphate buffer, pH 7.4 (1:2:0.8 [vol:vol:vol]; Bligh \& Dyer 1959). PLFAs were extracted, fractionated, saponified, and methylated using the protocol of Bligh \& Dyer (1959) as modified by White et al. (1979), Keinänen et al. (2003), and Taipale et al. (2008). For quantification, dipentadecanoylphostatidylcholine (c15:0) was added as an internal standard. Lipids were fractionated to neutral, glyco-, and phospholipids using 10, 20, and $10 \mathrm{ml}$ of chloroform, acetone, and methanol, respectively. The phospholipid fraction was evaporated to dryness under nitrogen flow. In mild alkaline methanolysis, the internal standards tridecanoic and nonadecanoic acid methyl esters were added, and fatty acids were saponified, methylated, and extracted as methylesters. The phospholipid fatty acids were run by GC-HRMS (VG AutoSpec). The modified timer program (Virtue et al. 1996) was used to separate fatty acid methyl esters from each other. First, the column was kept at $50^{\circ} \mathrm{C}$ for $1 \mathrm{~min}$, after which the temperature was raised first by $30^{\circ} \mathrm{C} \mathrm{min}{ }^{-1}$ to $110^{\circ} \mathrm{C}$, then by $1^{\circ} \mathrm{C} \mathrm{min}^{-1}$ to $220^{\circ} \mathrm{C}$, and finally by $10^{\circ} \mathrm{C} \mathrm{min}^{-1}$ to $300^{\circ} \mathrm{C}$. The program time was then $140 \mathrm{~min}$. The temperature of the injector was $290^{\circ} \mathrm{C}$, and the temperature of the source was $250^{\circ} \mathrm{C}$. The column used was Rtx-5MS, which was $30 \mathrm{~m}$ long with $0.25 \mathrm{~mm}$ ID $25 \mu \mathrm{m}$ phase. The positions of double bonds in monounsaturated phospholipid fatty acids (MUFAs) were determined by capillary GC-MS of their dimethyl disulfide (DMDS) adducts (Nichols et al. 1986).

PLFA biomarkers. Generally PLFAs were divided as typical for Gram-positive bacteria, for Gram-negative bacteria, and for phytoplankton. Iso- and anteisobranched PLFAs, a14:0, i15:0, a15:0, i16:0, i17:0, a17:0, and i18:0, are typical for Gram-positive bacteria (O'Leary \& Wilkinson 1988). According to the $16 \mathrm{~S}$ rRNA gene sequencing, Tetrasphaera sp. and Micrococcus luteus were closest to the dominant Actinobacteria, and thus iso- and anteiso-branched PLFAs were used as biomarkers for Actinobacteria in the oxic epilimnion. To estimate the contribution of Actinobacteria, it was assumed that iso- and anteiso-branched PLFAs contributed $80 \%$ (Wieser et al. 2002, McKenzie et al. 2006) of all PLFAs of Actinobacteria.

The 16 and 18 MUFAs, especially $16: 1 \omega 9 \mathrm{c}, 16: 1 \omega 7 \mathrm{c}$,

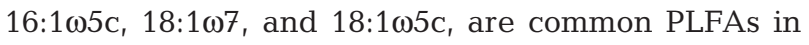
Gram-negative bacteria. 18:1 17 was used as a biomarker for Proteobacteria (Ratledge \& Wilkinson

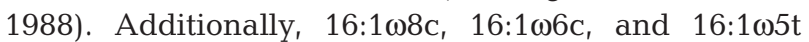
were considered specific PLFAs for MOB type I (Bowman et al. 1991). Correspondingly, 18:168c PLFA has been used as a specific biomarker for MOB type II (Guckert et al. 1991). To estimate the contribution of MOB, it was assumed that $16: 1 \omega 8 \mathrm{c}, 16: 1 \omega 6 \mathrm{c}$, and 16:105t PLFAs constituted 64\% (Wartiainen et al. 2006) of all MOB type I PLFAs. Br17:1, 10me16:0, and 17:1 are PLFA biomarkers for the sulfate-reducing genera Desulfovibrio, Desulfobacter, and Desulfobulbus, respectively (Macalady et al. 2000).

The typical PLFAs for Chlorobium sp. are 14:0, 16:0, and 16:1, which constitute $90 \%$ of all of their PLFAs (Kenyon 1972, Imhoff 2003). According to 16S rRNA gene sequencing, GSB belonged to Chlorobium sp. group 3a and thus it was assumed that 14:0 PLFAs constituted $16 \%$ (Imhoff 2003) of all GSB PLFAs. When estimating the biomass of Chlorobium sp., it was assumed that there are 2 fatty acids per 1 phosphate (P) molecule and $200 \mu \mathrm{g}$ PLFA per mg organic carbon; for Actinobacteria and Methylobacter sp., we assumed 2 fatty acids per $1 \mathrm{P}$ molecule and $380 \mu \mathrm{g}$ PLFA per mg organic carbon (Findlay 1996). 


\section{RESULTS}

\section{Physical and chemical parameters}

During summer stratification, only the uppermost meter of the epilimnion contained measurable oxygen, and, according to the decrease in redox potentials, the anoxic-oxic boundary layer was between 1.2 and $1.8 \mathrm{~m}$ (Fig. 1). Ammonium, iron, and methane concentrations increased down the water column, whereas sulfate concentration decreased slightly (Table 1). Methane concentrations were stable in the anoxic layers but decreased rapidly towards the surface (Table 1).

\section{Bacterial community composition}

Altogether, 435 clones of the 16S rRNA gene were sequenced from the different water layers. When all clones were pooled, most clones were assigned to the phyla Chlorobi (149 clones, 34\%) and Proteobacteria (142 clones, $33 \%$ ), of which most were Betaproteobacteria (103 clones, 23\%), Actinobacteria (43 clones, $10 \%)$, Planctomycetes (35 clones, 8\%), and Bacteroidetes (18 clones, $4 \%$; Fig. 2). Other phyla detected in minor proportions were TM7 (10 clones), Firmicutes (3 clones), Verrucomicrobia (3 clones), and Chloroflexi (3 clones). In addition, 1 or 2 clones were obtained from Acidobacteria, Chlamydia, Cyanobacteria, and OP11, and the rest were not classified. The number of different OTUs of sequences that shared $\geq 95 \%$ sequence similarity $\left(\mathrm{OTU}_{0.95}\right.$; Table 2 ) was equally high (42 to 49 ) in all water layers.

On the basis of $16 \mathrm{~S}$ rRNA gene sequencing, the relative abundance of dominant bacterial groups (Fig. 3A) varied vertically in the oxic and anoxic water columns. At the oxygenic surface (0 to $0.6 \mathrm{~m})$, sequences assigned to Actinobacteria (29\%) and Pro-

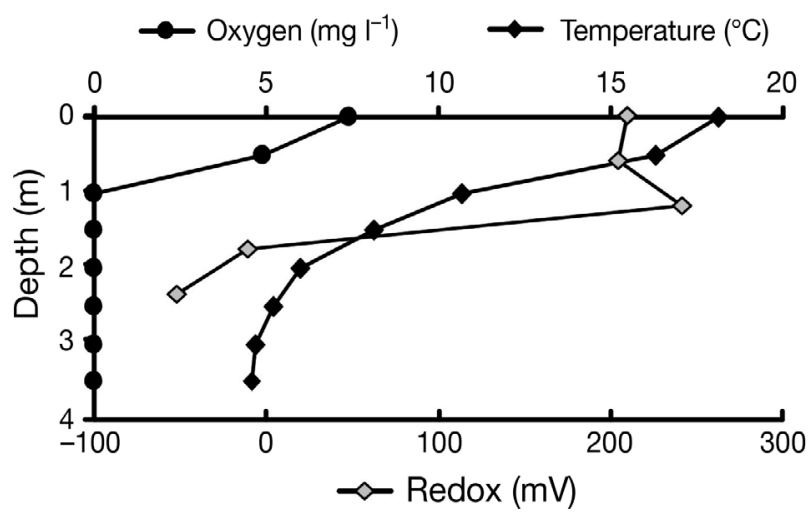

Fig. 1. Temperature, oxygen, and redox potential during summer stratification of Mekkojärvi on 1 August 2005
Table 1. Ammonium-nitrogen $\left(\mathrm{NH}_{4}-\mathrm{N}\right)$, iron $(\mathrm{Fe})$, sulfate $\left(\mathrm{SO}_{4}\right)$, and methane $\left(\mathrm{CH}_{4}\right)$ concentrations in successive water column layers of Mekkojärvi on 25 July 2005. nd: not determined

\begin{tabular}{|lcccc|}
\hline $\begin{array}{l}\text { Depth } \\
(\mathrm{m})\end{array}$ & $\begin{array}{c}\mathrm{NH}_{4}-\mathrm{N} \\
\left(\mu \mathrm{g} \mathrm{l}^{-1}\right)\end{array}$ & $\begin{array}{c}\mathrm{Fe} \\
\left(\mathrm{mg} \mathrm{l}^{-1}\right)\end{array}$ & $\begin{array}{c}\mathrm{SO}_{4} \\
\left(\mathrm{mg} \mathrm{l}^{-1}\right)\end{array}$ & $\begin{array}{c}\mathrm{CH}_{4} \\
\left(\mu \mathrm{mol} \mathrm{l}^{-1}\right)\end{array}$ \\
\hline $0-0.6$ & 33 & 1.0 & 8.0 & 11.3 \\
$0.6-1.2$ & 25 & 1.9 & 8.9 & 84.2 \\
$1.2-1.8$ & 85 & 2.7 & 8.4 & 138.4 \\
$1.8-2.4$ & 250 & 2.9 & 7.8 & 138.3 \\
$2.4-3.0$ & 330 & 2.9 & 6.6 & 135.1 \\
$3.0-3.6$ & 940 & 4.7 & 3.9 & $\mathrm{nd}$ \\
\hline
\end{tabular}

teobacteria (43\% of the $16 \mathrm{~S}$ rRNA gene clones) including the class Betaproteobacteria (30\%) were highly abundant, but the number of actinobacterial sequences decreased sharply together with the decreasing oxygen concentration. Both type I and II MOB were found at 0 to $0.6 \mathrm{~m}$. MOB type I sequences matched most closely with the type strains of Methylobacter psychrophilus (98.3\% similarity) and M. tundripaludum (98.9\% similarity), and the 2 obtained MOB type II sequences matched best with Methylocella palustris $(97 \%)$. In addition to $\mathrm{MOB}$, a sequence matching the methylotrophic Methylophilus sp. (95 to $96 \%$ similarity) was also found at 0 to $0.6 \mathrm{~m}$, but was especially abundant (4\% of all sequences) at 0.6 to $1.2 \mathrm{~m}$, where Chlorobi (39\% of sequences) and Betaproteobacteria (31\% of sequences) were the most abundant groups. Chlorobi was also the dominant microbial phylum at 1.2 to $1.8 \mathrm{~m}(47 \%)$ and at 1.8 to $3.0 \mathrm{~m}(43 \%)$. Methylobacter luteus was the only MOB type I sequence found at 0.6 to $1.2 \mathrm{~m}$. Gallionella ferruginea (98.7\% similarity with the type species) was a frequent species in the oxic layer at 0 to $0.6 \mathrm{~m}$. G. ferruginea and Rhodoferax sp. were the most frequent Betaproteobacteria at 1.2 to $1.8 \mathrm{~m}$. Planctomycetes and the thus far uncultivated phylum TM7 were also abundant bacterial phyla at 1.2 to $1.8 \mathrm{~m}$. Sequences of Deltaproteobacteria were abundant at 1.8 to $3.0 \mathrm{~m}$ close to the bottom, where the Fe(III)-reducing bacterium Geobacter psychrophilus ( $7 \%$ of all sequences from the hypolimnion) was the closest cultivated organism (with 94 to $99.75 \%$ sequence identity) of most of the sequences except 1 sequence that was closest to the sulfate-reducing bacterium STO23. However, at other depths, single deltaproteobacterial sequences were obtained that were affiliated to Pelobacter propionicus, Desulfocapsa sp. Cad626, Desulforomonadales sp. TC37, and to the unidentified bacterium ROMEm4sh208, which are all chemolithotrophic bacteria that gain their sole electron acceptors from sulfur or iron compounds. 


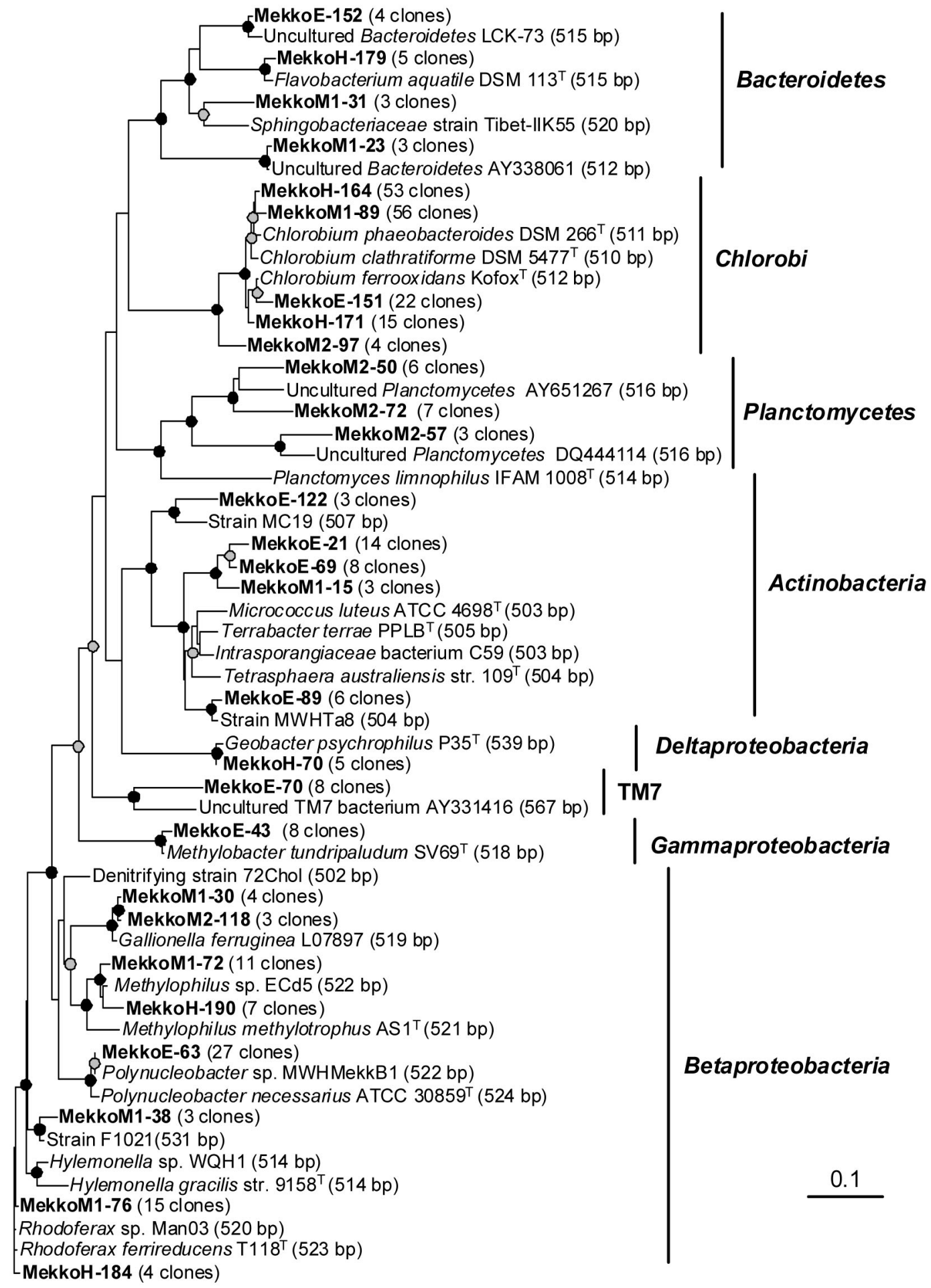

Fig. 2. Phylogenetic relationships of abundant Mekkojärvi phylotypes and their closest relatives based on partial 16S rRNA gene sequences. The phylogenetic tree was constructed from 367 aligned nucleotide positions using the neighbor-joining method with Kimura correction for multiple substitutions. A representative of each major OTU $\mathrm{O}_{05}$ group with 3 or more clones has been selected for the figure. The number of clones in each group is indicated after the clone name. The LH-PCR length (bp) of related sequences is indicated after the organism name or EMBL accession number. The clones from epi-, upper meta-, lower meta-, and hypolimnion are indicated by the following prefixes: MekkoE, MekkoM1, MekkoM2, and MekkoH. Nodes supported by bootstrap values between 70 to $90 \%$ and 90 to $100 \%$ are shown by gray and black circles, respectively. The scale bar indicates 0.1 changes per nucleotide position 
Table 2. Number of different 16S rRNA gene clones sharing less than $95 \%$ and $99 \%$ sequence similarity in 4 depth zones of Mekkojärvi. OTU: operational taxonomic unit

\begin{tabular}{|lcccc|}
\hline Layer & Depth $(\mathrm{m})$ & Clones & OTU $_{0.95}$ & OTU $_{0.99}$ \\
\hline Epilimnion & $0-0.6$ & 92 & 47 & 69 \\
Metalimnion 1 & $0.6-1.2$ & 124 & 49 & 68 \\
Metalimnion 2 & $1.2-1.8$ & 113 & 42 & 56 \\
Hypolimnion & $1.8-3.0$ & 106 & 49 & 72 \\
Total & & 435 & 132 & 225 \\
\hline
\end{tabular}

\section{Diversity of sequences of the phylum Chlorobi}

More detailed comparative phylogenetic clustering was done for the sequences belonging to the most abundant bacterial phyla Chlorobi and Actinobacteria and the class Betaproteobacteria. All 16S rRNA gene sequences of the phylum Chlorobi were assigned to Chlorobium group 3a (Alexander et al. 2002) sharing 96 to $99 \%$ similarity to the sequences of the type strains of Chlorobium phaeobacteroides, C. clathratiforme, and $C$. ferrooxidans. In the neighbor-joining analysis (Appendix 1A, available as AME Supplementary Material at www.int-res.com/articles/suppl/ a055p001_app.pdf), all 149 Chlorobi sequences clustered with the aforementioned Chlorobium type strains and not with the Chlorobaculum type strains (Imhoff et al. 2003). Of the Chlorobi sequences, $77 \%$ clustered with C. phaeobacteroides, $16 \%$ with C. ferrooxidans, and $8 \%$ with $C$. clathratiforme, but the
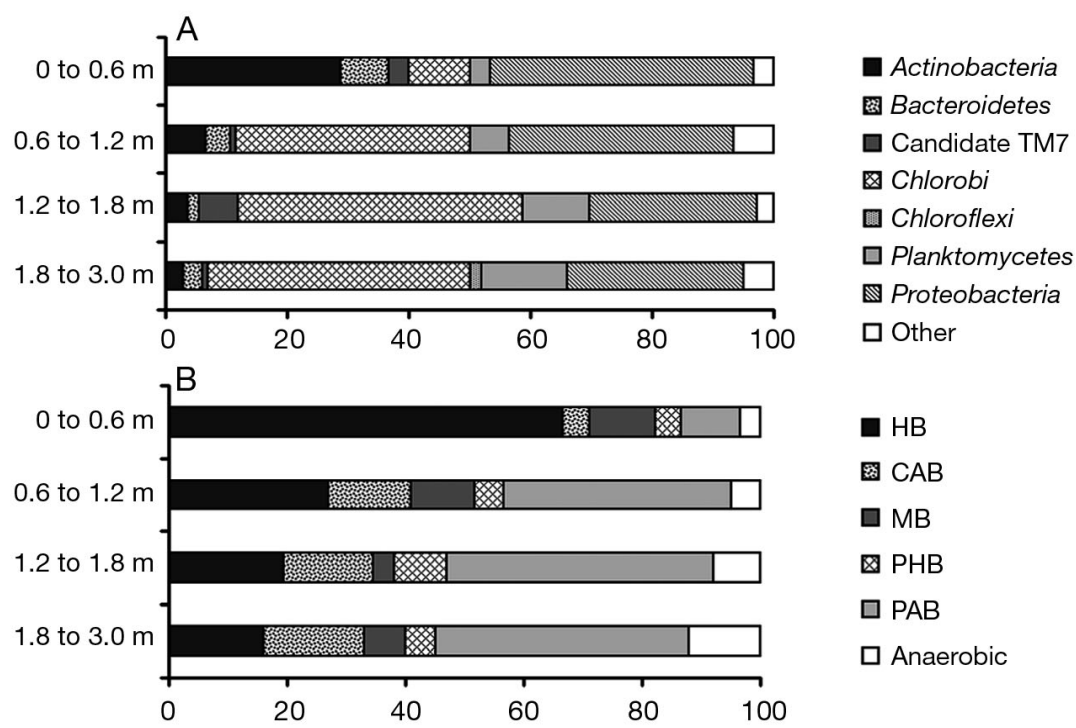

Fig. 3. Percentage contribution of 16S rRNA gene sequences in the water column of Mekkojärvi assigned to (A) major bacterial phyla and (B) different bacterial functional groups: heterotrophic bacteria (HB), photoheterotrophic bacteria (PHB), methylotrophic bacteria including methanotrophs and other C1-compound-utilizing bacteria (MB), photoautotrophic bacteria (PAB), chemoautotrophic bacteria (CAB), and other anaerobic bacteria branching of the tree was not supported by high bootstrapping values. The sequences clustering with $C$. ferrooxidans were obtained from the hypolimnion or lower metalimnion, but C. phaeobacteroides and $C$. clathratiforme sequences were obtained from different water depths including the epilimnion, showing no vertical specialization.

\section{Diversity of sequences of the class Betaproteobacteria}

Betaproteobacteria was the largest class in the phylum Proteobacteria in Mekkojärvi. The detailed phylogenetic analysis (Appendix 1B,C) showed that the Polynucleobacter necessarius cluster (Zwart et al. 2002) was very common in the oxic epilimnion of Mekkojärvi, and also in lower water phases (0.6 to $3.0 \mathrm{~m})$, showing adaptation to microaerobic and anaerobic conditions. All $P$. necessarius cluster sequences were inside the $P$. necessarius subcluster PnecC (Hahn 2003), except a single sequence of the subcluster PnecA. These identical or nearly identical sequences formed a coherent group with, e.g. isolate MWH-MekkB1 previously isolated from Mekkojärvi (Vannini et al. 2007) and clone Fuku35 obtained from the clone library of the acidified bog lake Grosse Fuchskuhle (Glöckner et al. 2000). Most other betaproteobacterial sequences were outside the other typical freshwater clusters Rhodoferax sp. BAL47, GKS16, GKS 98, Ralstonia pickettii, and LD28. Although not close to Rhodoferax sp. BAL47 or GKS16, a large number of different Rhodoferaxaffiliated but still not closely related phylotypes were detected. A diverse cluster of Methylophilus-affiliated sequences was observed in the metalimnetic oxicanoxic boundary layer. All sequences that were classified to Nitrosomonadales were related to Gallionella (family Gallionellaceae), thus showing a lack of betaproteobacterial ammonia oxidizers of the family Nitrosomonadaceae. Sequences belonging to known ammoniaoxidizing gammaproteobacterial bacteria (genus Nitrosococcus) were not detected either, but most of the gammaproteobacterial sequences (12/18) were derived from MOB (family Methylococcaceae).

\section{Diversity of sequences of the phylum Actinobacteria}

The similarity value of most actinobacterial sequences and sequences of clos- 


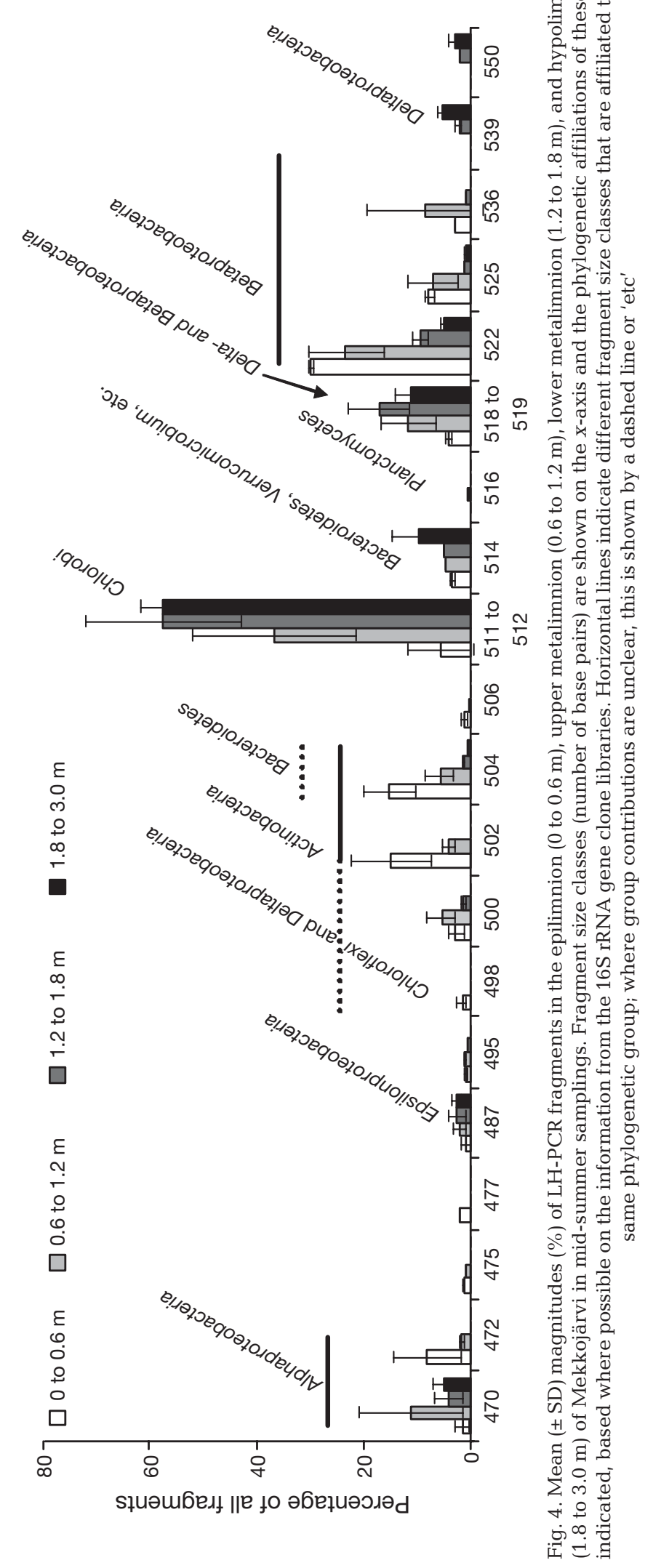

est cultivated organisms ranged from 94 to $96 \%$. The sequences could be grouped into 4 coherent clusters, which were clearly separated by $\mathrm{OTU}_{0.95}$ grouping (Fig. 2) as well as in the more detailed trees (Appendix 1D, E). The largest groups of actinobacterial sequences were obtained from the typical freshwater bacteria group hgcI clustered by Glöckner et al. (2000), of which most (22) sequences (represented by MekkoE-21 and MekkoE69) clustered with subgroup STA2-30, designated by Zwart et al. (2002), and only 3 sequences (represented by Mekko M1-15 in Fig. 2) clustered with the other hgcI-group ACK-M1 (Zwart et al. 2002). In the other tree with the sequences collected and clustered by Warnecke et al. (2004) (Appen$\operatorname{dix} 1 \mathrm{E})$, all of these sequences were affiliated into the lineage acI (acI-B and acI-A, repectively). Six closely related actinobacterial sequences obtained from the oxic 0 to $0.6 \mathrm{~m}$ (represented by OTU MekkoE-89) matched best with the unidentified actinobacterial isolate MWH-Ta8 and clones belonging to cluster acII (Warnecke et al. (2004). Another small group of sequences clustered with actinobacterial isolate MC19 as well as Grosse Fuchskuhle clone FukuS94 (accession number AJ290019; Glöckner et al. 2000). The assignation of this group of sequences to specific freshwater clusters earlier described for Actinobacteria remains indistinct, but was most closely related to cluster acIV by Warnecke et al. (2004), which corresponds to the group C111 after the classification by Urbach et al. (2001) including subgroups MED0-06, CL500-29, or URK0-14 clustered by Zwart et al. (2002; Appen$\operatorname{dix} 1 \mathrm{D}, \mathrm{E})$.

\section{Functional affiliation of the Mekkojärvi 16S rRNA gene sequences}

Tentative functions of bacteria behind the 16S rRNA sequences were predicted using information of closest matching classified organisms. In candidate phyla with no cultivated representatives and in cases when the sequences could not be classified, the sequences were considered heterotrophic. According to the 16S rRNA gene library data, sequences affiliated with heterotrophic bacteria (HB) dominated at 0 to $0.6 \mathrm{~m}(68 \%$ of all bacterial sequences in the epilimnion), but contributed only 16 to $27 \%$ of all bacterial sequences at 0.6 to $3.0 \mathrm{~m}$ (Fig. 3B). Methylotrophic bacteria (MB), including sequences assigned to Methylophilus, Methylobacter, and Methylocapsa, were more abundant at 0 to $0.6 \mathrm{~m}$ and 0.6 to $1.2 \mathrm{~m} \mathrm{(11 \% )} \mathrm{than} \mathrm{at} 1.2$ to $1.8 \mathrm{~m}(4 \%)$ or at 1.8 to $3.0 \mathrm{~m}(7 \%)$. Sequences assigned to chemoautotrophic bacteria were equally dispersed (14 to $17 \%$ ) in the water column over 0.6 to $3.0 \mathrm{~m}$, in which layers of photoautotrophic bacteria (PAB) formed the most 
Table 3. Vertical characteristics of Mekkojärvi in different depth layers in mid-summer (mean of 3 samplings \pm SD). Prokaryotic cell numbers and biomasses are based on microscopy. Estimation of the relative abundance of specific bacterial groups is based on rRNA gene clone libraries, LH-PCR biomarkers, and indicative fatty acids. The LH-PCR biomarker sizes refer to Actinobacteria (502 bp and $504 \mathrm{bp}$ ), Chlorobium sp. (511/512 bp), Methylobacter sp. (518/519 bp), and Betaproteobacteria including Methylophilus sp. and Polynucleobacter (522 bp). NE: not estimated due to overlapping phospholipid fatty acid (PLFA) biomarkers

\begin{tabular}{|c|c|c|c|c|}
\hline \multirow{2}{*}{ Characteristic } & \multicolumn{4}{|c|}{ Depth $(\mathrm{m})$} \\
\hline & $0-0.6$ & $0.6-1.2$ & $1.2-1.8$ & $1.8-3.0$ \\
\hline $\mathrm{DOC}\left(\mathrm{mg} \mathrm{C} \mathrm{l}^{-1}\right)$ & $22 \pm 2$ & $21 \pm 1$ & $24 \pm 1$ & $22 \pm 1$ \\
\hline $\mathrm{POC}\left(\mu \mathrm{g} \mathrm{C} 1^{-1}\right)$ & $260 \pm 9$ & $390 \pm 66$ & $1210 \pm 128$ & $1270 \pm 402$ \\
\hline Prokaryotic cell number $\left(\times 10^{6}\right.$ cells ml $\left.{ }^{-1}\right)$ & $2.4 \pm 1.0$ & $2.9 \pm 1.5$ & $3.3 \pm 1.0$ & $5.1 \pm 1.8$ \\
\hline Prokaryotic biomass $\left(\mu \mathrm{g} \mathrm{Cl}^{-1}\right)$ & $28 \pm 11$ & $31 \pm 16$ & $59 \pm 26$ & $115 \pm 46$ \\
\hline Total PLFA (pmol ml-1) & $76 \pm 24$ & $134 \pm 71$ & $405 \pm 96$ & $440 \pm 136$ \\
\hline Bacterial PLFA (pmol ml ${ }^{-1}$ ) & $59 \pm 13$ & $121 \pm 66$ & $376 \pm 97$ & $416 \pm 127$ \\
\hline $16: 1 \omega 7\left(\mathrm{pmol} \mathrm{ml} l^{-1}\right)$ & $18 \pm 3$ & $45 \pm 21$ & $151 \pm 23$ & $183 \pm 35$ \\
\hline \multicolumn{5}{|l|}{ 16S rRNA gene ( $\%$ of sequences) } \\
\hline Actinobacteria & 28.9 & 6.6 & 3.7 & 3.0 \\
\hline Chlorobium sp. & 10.0 & 38.5 & 46.8 & 43.0 \\
\hline Methylobacter sp. & 4.0 & 1.8 & 1.6 & 3.3 \\
\hline Betaproteobacteria (all) & 30.0 & 31.1 & 22.0 & 15.0 \\
\hline Methylophilus sp. & 3.0 & 10.1 & 0.8 & 3.3 \\
\hline Polynucleobacter sp. & 14.0 & 8.3 & 3.3 & 3.3 \\
\hline \multicolumn{5}{|l|}{ LH-PCR (\% of total band area) } \\
\hline 502 and 504 bp & $30 \pm 12$ & $7 \pm 6$ & $1 \pm 0.3$ & 1 \\
\hline $511 / 512 \mathrm{bp}$ & $6 \pm 6$ & $37 \pm 15$ & $57 \pm 15$ & $58 \pm 4$ \\
\hline $518 / 519 \mathrm{bp}$ & $4 \pm 0.7$ & $12 \pm 5$ & $17 \pm 6$ & $11 \pm 3$ \\
\hline $522 \mathrm{bp}$ & $30 \pm 0.4$ & $23 \pm 7$ & $9 \pm 2$ & $5 \pm 0.9$ \\
\hline \multicolumn{5}{|l|}{ 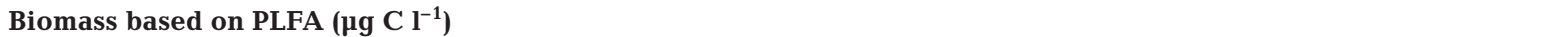 } \\
\hline Actinobacteria & $27 \pm 5$ & NE & NE & NE \\
\hline Methylobacter sp. & $6 \pm 1$ & $26 \pm 28$ & $99 \pm 65$ & $79 \pm 90$ \\
\hline Chlorobium sp. & NE & $80 \pm 28$ & $199 \pm 55$ & $238 \pm 71$ \\
\hline
\end{tabular}

abundant (38 to $45 \%$ ) functional bacterial group to which our sequences were assigned. Anaerobic metabolism was naturally more common in the deeper parts of the water column, and sequences of such types contributed $8 \%$ and $12 \%$ of all sequences at 1.2 to $1.8 \mathrm{~m}$ and 1.8 to $3.0 \mathrm{~m}$, respectively.

\section{Linking LH-PCR profiles and 16S rRNA gene sequences}

According to the LH-PCR results, the diversity of different separated fragment sizes was higher at 0 to $0.6 \mathrm{~m} \mathrm{(18)}$ and at 0.6 to $1.2 \mathrm{~m} \mathrm{(12} \mathrm{to} \mathrm{16)} \mathrm{than} \mathrm{at} 1.2$ to $3.0 \mathrm{~m}$ (6 to 11). The fragment size of $522 \mathrm{bp}$ was the most abundant $(\sim 30 \%)$ size at 0 to $0.6 \mathrm{~m}$ (Fig. 4 ), whereas the fragment size of $511 \mathrm{bp}$ dominated in other layers, especially in the anoxic water column $(1.2$ to $3 \mathrm{~m})$, where it contributed 45 to $74 \%$ of all fragments (Table 3 ). The sequence analysis allowed us to connect sequence data with distinct lengths in the LH-PCR profiles. Since these sequences were partial and did not always cover the whole length of the LH-PCR fragment, closest matching reference sequences were used to aid the size calculation together with our sequences. Sizes calculated from sequences matched well with the major sequence lengths in the LH-PCR analysis, with some exceptions. All sequences with sizes below $473 \mathrm{bp}$ were assigned to Alphaproteobacteria (Fig. 4) including MOB type II (Methylosarcina and Methylocella). The sequence sizes 502 to $504 \mathrm{bp}$ were assigned to the phylum Actinobacteria (to Tetrasphaera sp. and Micrococcus luteus-like bacteria), and thus these fragments could be used as actinobacterial biomarkers in Mekkojärvi. The sequence size 512 bp was a specific biomarker for Chlorobi, especially for the genus Chlorobium, although the observed size of this specific fragment was $511 \mathrm{bp}$ in the LH-PCR analysis, due to small sequence-based differences in the mobility of this fragment compared to the size markers. Fragment size 514 bp was derived from sequences of Verrucomicrobia and Bacteroidetes. The next longest sequence size found was $516 \mathrm{bp}$, which was assigned to the phylum Planctomycetes. The sequence size of 518 bp was assigned to all observed type I MOB sequences (Methylobacter). Sequence size 519 bp belonged to Gallionella ferruginea, but the fragment sizes 518 and 519 bp could not practically be separated from each other and were therefore combined. 

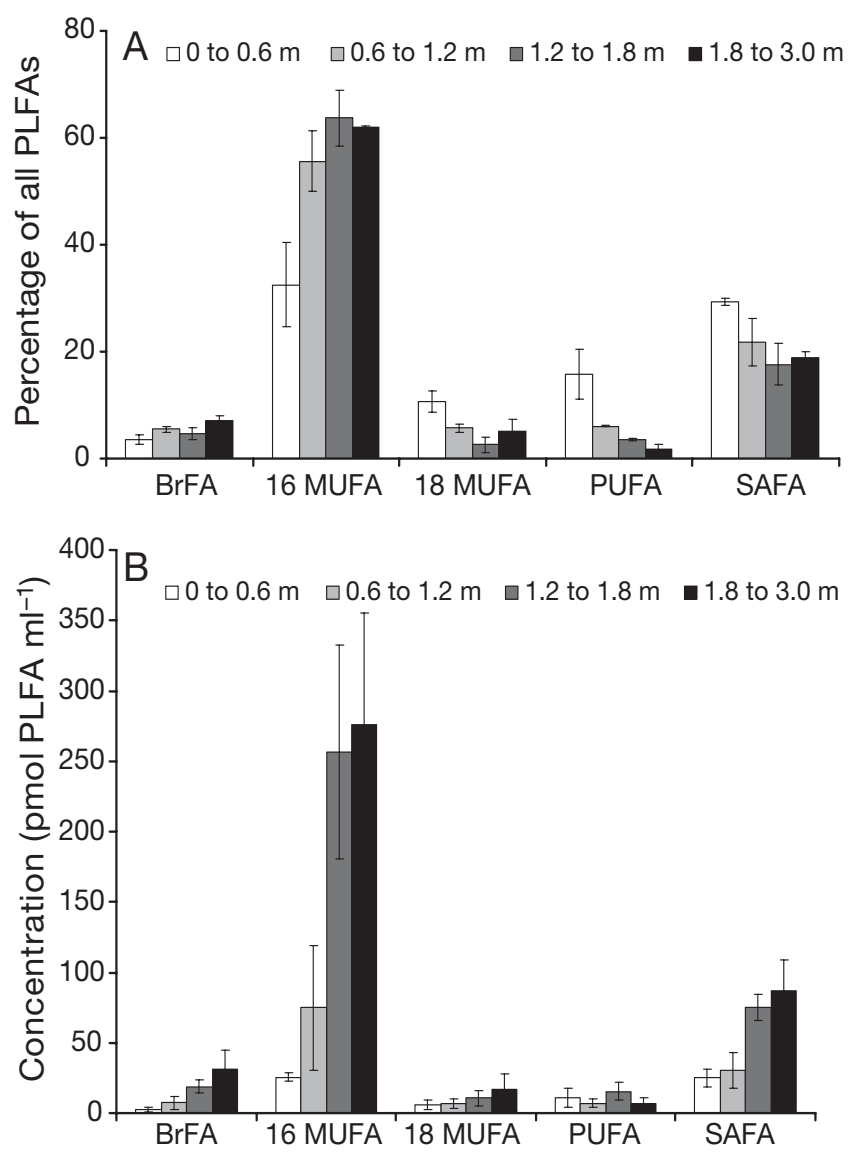

Fig. 5. (A) Magnitude (mol\%) and (B) concentration (pmol PLFA $\mathrm{ml}^{-1}$ ) of branched fatty acids (BrFA, common FAs among Gram-positive bacteria), 16 and 18 monounsaturated fatty acids (MUFAs, common FAs in Gram-negative bacteria), polyunsaturated fatty acids (PUFAs, typical in phytoplankton), and saturated fatty acids (SAFAs, typical in terrestrial litter) in the different depth layers of Mekkojärvi in midsummer (mean $\pm \mathrm{SD}$ ). PLFA: phospholipid fatty acid

The sequence size 522 bp was assigned to many genera among Betaproteobacteria, e.g. Polynucleobacter sp., Methylophilus sp. (also size $536 \mathrm{bp}$ ), and Rhodoferax sp., and thus this fragment cannot be used as a specific biomarker of any genus but only as a biomarker of the Betaproteobacteria. Deltaproteobacterial sequences closely resembling Geobacter psychrophilus $^{\mathrm{T}}$ were assigned to the LH-PCR length $539 \mathrm{bp}$. According to $16 \mathrm{~S}$ rRNA gene sequencing of the 4 Mekkojärvi clone libraries, the fragment size $567 \mathrm{bp}$ would have matched sequences classified to candidate phyla TM7 and OP11 (but only with low identities of $<90 \%$ ); however, such sequence size was excluded from the LH-PCR data analysis, since the size exceeded the expected bacterial partial $16 \mathrm{~S}$ rRNA sequences size (465 to $565 \mathrm{bp}$ ) using primers $27 \mathrm{~F}$ and PRUN518, based on a previous analysis of cultivated organisms (Tiirola et al. 2003).

\section{Contribution of bacterial and phytoplankton PLFAs}

The total PLFA concentration increased nearly 6fold, from $76 \mathrm{pmol} \mathrm{m} l^{-1}$ at 0 to $0.6 \mathrm{~m}$ to $405-440 \mathrm{pmol}$ $\mathrm{ml}^{-1}$ at 1.2 to $3.0 \mathrm{~m}$ (Table 3), and bacterial PLFAs contributed from 72 to $97 \%$ of all PLFAs (Fig. 5A). A similar increase was observed for estimates of prokaryotic biomass calculated from cell numbers and cell sizes obtained by microscopy, from $28 \mu \mathrm{g} \mathrm{Cl}^{-1}$ in the epilimnion to $115 \mu \mathrm{g} \mathrm{Cl}^{-1}$ in the hypolimnion (Table 3), while the cell numbers and the average cell size doubled. However, cell size estimation by microscopy is demanding and partly subjective, so fatty acid results are here considered more reliable for the estimation of the microbial biomass.

Altogether, 64 PLFAs from seston were detected and identified, but only a few of these were abundant in the water column of Mekkojärvi. Among all PLFAs, the 16 MUFAs were the most common (Fig. 5) and contributed 27 to $38 \%$ of all PLFA molecules (measured by the integrated area in the GC-MS) at 0 to $0.6 \mathrm{~m}$, and even 60 to $67 \%$ of all PLFAs at 0.6 to $3.0 \mathrm{~m}$. Among 16 MUFAs, $16: 1 \omega 7 \mathrm{C}$ was the most frequent individual PLFA on all sampling days and contributed 38 to $67 \%$ of bacterial PLFAs in the whole water column, with the concentration rising from 18 to 183 pmol PLFA ml ${ }^{-1}$ from the surface to the bottom. According to the PLFAs typical of type I MOB (16:1 $108 \mathrm{c}$ and $16: 1 \omega 5 \mathrm{t})$, the biomass of these bacteria (Table 3) increased between 0 to $0.6 \mathrm{~m}$ and 1.2 to $\left.1.8 \mathrm{~m} \mathrm{(6} \mathrm{to} 99 \mu \mathrm{g} \mathrm{C} \mathrm{l}^{-1}\right)$ but was still high at 1.8 to $\left.3.0 \mathrm{~m} \mathrm{(79} \mathrm{g} \mathrm{C} \mathrm{C}^{-1}\right)$. Typical MOB type II

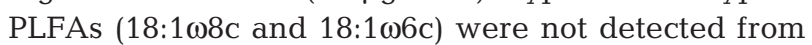
the water column. Iso- and anteiso-branched PLFAs comprised 2 to $4 \%$ of all and 4 to $6 \%$ of bacterial PLFAs at 0 to $0.6 \mathrm{~m}$. Based on PLFA profiles of Micrococcus luteus and Tetrasphaera sp., it was estimated that Actinobacteria constituted only 4 to $9 \%$ of the epilimnetic bacterial community with a biomass of $27 \pm 5 \mu \mathrm{g} \mathrm{C} \mathrm{l}^{-1}$ (Table 3). However, iso and anteisobranched PLFAs were more frequent at 1.8 to $3.0 \mathrm{~m} \mathrm{(6}$ to $7 \%$ of all and 6 to $8 \%$ of bacterial PLFAs) than at 0 to $0.6 \mathrm{~m}$, due to the high abundance of a 15:0 FA (4\% of all PLFAs), which has been previously related to Chlorobium sp. (S. Taipale unpubl.). From the abundance of 14:0, it was estimated that Chlorobium sp. constituted 36 to $73 \%$ of the bacterial biomass at 0.6 to $3.0 \mathrm{~m}$.

Polyunsaturated fatty acids (PUFAs) were most common at 0 to $0.6 \mathrm{~m}$. PUFAs are abundant in phytoplankton membranes, and here they contributed 12 to $19 \%$ of all PLFAs at 0 to $0.6 \mathrm{~m}$. The 18 MUFAs were also most abundant at 0 to $0.6 \mathrm{~m}$ ( 4 to $12 \%$ of all) of Mekkojärvi. The 18:167c PLFA typical of Proteobacteria was the major 18 MUFA and contributed 4 to $14 \%$ of all bacterial PLFAs at 0 to $1.2 \mathrm{~m}$; its concentration was $6 \pm$ 
3 pmol PLFA ml $\mathrm{m}^{-1}$ at 0 to $1.2 \mathrm{~m}$ and $7 \pm 5$ pmol PLFA $\mathrm{ml}^{-1}$ at 1.2 to $3.0 \mathrm{~m}$. A minor amount of $18: 1 \omega 9 \mathrm{c}$, a typical phytoplankton PLFA, was also detected.

The contribution of saturated fatty acids (SAFAs) was highest at 0 to $0.6 \mathrm{~m}$ (29 to $37 \%$ ), but contributed less than $27 \%$ of all PLFAs at 0.6 to $3.0 \mathrm{~m}$. The most abundant SAFA was palmitic acid $(16: 0,8$ to $17 \%)$, which is a frequent PLFA in bacteria and phytoplankton and thus not specific for any group. Additionally, 14:0 FA had the highest contribution in both the oxic eplilimnion (9 to $17 \%$ of all) and the anoxic hypolimnion (6 to $7 \%$ of all). Other SAFAs contributed less than $3.5 \%$ of all PLFAs.

PLFAs typical of sulfate-reducing bacteria were also detected. A minor contribution $(<1 \%$ of all) of Desulfobacteria-typical 10Me16:0 was detected at all depths, but especially in the anoxic water column. Traces of br17:1 and 17:1 PLFAs were detected and thus possibly reflected the presence of Desulfovibrio and Desulfobulbus species in the anoxic water column (1.2 to $3.0 \mathrm{~m})$. Minor contributions ( $<2 \%$ of all PLFAs)

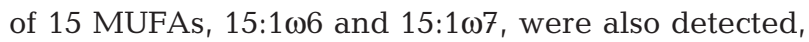
especially in the anoxic water column.

\section{DISCUSSION}

In this study, Chlorobi, Betaproteobacteria, and Actinobacteria were the major contributors to the microbial community of an oxygen-stratified polyhumic lake, according to $16 \mathrm{~S}$ rRNA gene sequencing, LH-PCR, and PLFA analysis. The relative number of Actinobacteria decreased and Chlorobi increased in the anoxic water layers. Affiliation of the 16S rRNA gene sequences to their closest cultivated neighbor organisms provided entry to the possible traits of bacteria, and showed that bacteria assigned to classical heterotrophic genera dominated only in the oxic epilimnion of Mekkojärvi. However, it is important to remember that small differences at the 16S rRNA level may hide considerable differences at the levels of genome and phenotype. Another consideration is that the diversity of sequences in clone libraries may not quantitatively reflect the diversity of the sequence types present in the original sample, due to limited size of the clone libraries and well-known sources for biases generated in the DNA extraction process, PCR amplification, and cloning steps (for a review see von Wintzingerode et al. 1997). In this study, the data from gene libraries were strengthened by the length heterogeneity analysis of the PCR-amplified 16S rRNA gene (LH-PCR; Suzuki et al. 1998). This provided a more accurate tool for the analysis of the relative abundance of distinct bacterial groups, as sequencing covers usually only hundreds of molecules, whereas profiling covers the major diver- sity of millions of molecules. According to our LH-PCR and 16S rRNA gene sequencing results, many of the LH-PCR fragment sizes were specific biomarkers for some distinct bacterial groups in this lake. All fragments less than $473 \mathrm{bp}$ in length belonged to Alphaproteobacteria (including MOB type II); 502 to $504 \mathrm{bp}$ fragments belonged to Actinobacteria, and those of $511 / 512$ bp to Chlorobium sp. In addition to these biomarkers, fragments of 518/519 bp belonged to Methylobacter or Gallionella genera and fragments of $522 \mathrm{bp}$ to various Betaproteobacteria, especially the genera Polynucleobacter and Methylophilus. This kind of biomarker technique can be useful when studying seasonal changes in the microbial communities in humic lakes.

Habitat-specific clustering has shown that most bacteria inhabiting freshwater systems are indigenous to freshwater and distinct from soil or other ecosystems, and 'typical freshwater bacteria' included 34 phylogenetic clusters that appeared to exhibit a global distribution (Zwart et al. 2002). In this study, HB consisted mainly of Actinobacteria and Betaproteobacteria, which is consistent with earlier results from fresh waters (Glöckner et al. 2000, Zwart et al. 2002, van der Gucht et al. 2005), including humic lakes (Burkert et al. 2003, Grossart et al. 2008). Actinobacteria were typical bacteria of the oxic surface water in Mekkojärvi; their clone sequences and specific LH-PCR fragments contributed $29 \%$ and 21 to $43 \%$ (variation from the 3 sampling times) of all epilimnion sequences, respectively, but their relative contribution in the 16S rRNA gene pool decreased rapidly in the anoxic water layers, in which the total bacterial PLFA biomass was 6 times higher than in the epilimnion. Most actinobacterial sequences were not close to cultivated organisms but clustered with the sequences of the cluster acI-B (Warnecke et al. 2004), also known as hgcI subcluster STA2-30 (Zwart et al. 2002). Among Betaproteobacteria, Polynucleobacter sp. was the most common genus (11\% of all $16 \mathrm{~S}$ rRNA gene sequences in the epilimnion) inhabiting especially the oxic epilimnion, but some sequences were also obtained from the anoxic layers, although fewer in relative numbers. Polynucleobacter sequences of Mekkojärvi belonged to the subcluster PnecC (Hahn 2003), which seems to be a group characteristic of humic and acidic environments (Grossart et al. 2008). Isolates of Polynucleobacter necessarius have previously been obtained from Mekkojärvi and from lakes, ponds, and rivers in central Europe, China, and East Africa by the filtrationacclimatization method separating these extremely small bacteria using $0.2 \mu \mathrm{m}$ pore size filters (Hahn 2003, Vannini et al. 2007). There are indications that $P$. necessarius cluster bacteria efficiently use allochthonous humic substances (Burkert et al. 2003, Grossart et 
al. 2008). In the LH-PCR analysis of Mekkojärvi, the sequence size 522 bp dominated ( 30\% of all fragments) in the epilimnion, reflecting the importance of Polynucleobacter and Methylophilus.

According to the PLFA profiles, Actinobacteria would have constituted only 4 to $8 \%$ of epilimnetic bacterioplankton, whereas Gram-negative typical PLFAs were richly abundant. The higher contribution of 18:1 107 PLFA than of iso- and anteiso-branched PLFAs in the epilimnion implies a dominance of Proteobacteria over Actinobacteria among the HB community. DNA results indicated a much higher importance of Actinobacteria than did PLFA results. This could arise if in the PLFA analysis some small Actinobacteria cells passed through GF/F filters, which have a nominal pore size of about $0.7 \mu \mathrm{m}$. The small size could also lead to higher 16S rRNA gene:biomass ratios, thus leading to overestimations when the $16 \mathrm{~S}$ rRNA gene is the sole base of the community composition analysis. Terrestrial inputs might also include inactive or dead cells, in which PLFAs are already decomposed but DNA remains. Slow degradation of DNA might also explain why some Chlorobium sp. sequences were derived from the oxic epilimnion, although this genus is considered strictly anaerobic. Several reasons might therefore lead to slightly differing results when molecular and chemotaxonomical data are compared, and the results might depend on whether BCC is expressed as biomass, cell numbers, or 16S rRNA gene copies.

Methylotrophic bacteria in Mekkojärvi were assigned to the methanol-utilizing genus Methylophilus sp. and type I MOB belonging to the genus Methylobacter previously found in many other freshwater systems (Zwart et al. 2002, Eller et al. 2005a). The precise contribution of Methylobacter sp. was difficult to estimate using LH-PCR fragments due to the closely similar fragment size of Gallionella ferruginea, which interfered with the specific LH-PCR fragment indicating $\mathrm{MOB}$ in the metalimnion. However, according to fluorescence in situ hybridization (FISH) results (G. Eller unpubl.), the contribution of MOB I to all DAPIstained cells was higher in the epilimnion and upper metalimnion (3.4 and $8.2 \%$, respectively) than in the lower metalimnion and hypolimnion (2.6 and $3.1 \%$ ), which is in good accord with our clone libraries, but much less than predicted from the fatty acid analysis. Although fatty acids specific for MOB type II were not found from the water column, a single sequence resembling Methylocella palustris was found in the epilimnion, which shows that MOB types I and II were both present, although not dominant in the water column. Additionally, sulfate concentration was high in the anoxic water column, so an interesting question lies in the role of anaerobic methane oxidation coupled with sulfate reduction, which has been detected in some anoxic fresh waters (Eller et al. 2005b). Specific Deltaproteobacteria living in partnership with the Archaea capable of reverse methanogenesis often fall into the Desulfosarcina/ Desulfococcus cluster in the order Desulfobacterales. Fatty acids referring to the deltaproteobacterial sulfate reducers were detected, but only 2 of the 10 deltaproteobacterial sequences were classified to the order Desulfobacterales.

The study showed the dominance of photoautrophic GSB in all water layers of Mekkojärvi, except in the fully aerobic epilimnion. Although this finding differs from earlier 16S rRNA gene libraries of other lake ecosystems (e.g. Glöckner et al. 2000, Percent et al. 2008), pigment analysis has shown that these bacteria commonly thrive in the metalimnia of humic lakes (Vila et al. 1998). The lack of Chlorobi from the list of typical freshwater bacteria (Zwart et al. 2002) is most probably connected to the fact that earlier studies concentrated on aerobic systems and did not compare the spatial distribution of bacteria in lakes with oxygen stratification. The dominance of Chlorobium sp. is in accordance with the microscopic and bacteriochlorophyll $d$ observations by Arvola et al. (1992) and Kuuppo-Leinikki \& Salonen (1992). The sequences of GSB were assigned to Chlorobium group 3a (Alexander et al. 2002) and were close to Chlorobium ferrooxidans, C. phaeobacteroides, or Chlorobium clathratiforme. The 16S rRNA genes of these species are very similar (Imhoff 2003), which makes exact differentiation using this gene difficult.

Development of phototrophic sulfur bacteria requires the presence of both light and anaerobic conditions, and these 2 requirements can coincide in the steeply stratified, high DOC content lake, despite the dark color and hence very low irradiances in the hypolimnion. GSB are usually found in deeper layers than the purple sulfur bacteria, since they tolerate higher $\mathrm{H}_{2} \mathrm{~S}$ concentrations and require less light. The high biomass of photosynthetic bacteria in the metaand hypolimnion of Mekkojärvi is remarkable in view of the shallow penetration of light into this lake $1 \%$ level of surface light at 0.75 to $1.0 \mathrm{~m}$; Kuuppo-Leinikki \& Salonen 1992). Chlorobiaceae have modest radiation requirements, which is a consequence of their unique, highly effective light-harvesting chlorosomes (Trüper \& Pfennig 1992), but low in situ doubling times (3.1 to 26 yr) of Chlorobiaceae have still been calculated for the Black Sea chemocline (Manske et al. 2005). The high ammonium concentration found in Mekkojärvi in the anoxic water layers (Kuuppo-Leinikki \& Salonen 1992) would also facilitate the growth of Chlorobium, which prefer ammonium as a nitrogen source (Trüper \& Pfennig 1992). GSB can create high biomass in a thin water layer (Kuuppo-Leinikki \& Salonen 1992), but our 
results suggest that their biomass was high in the whole anoxic water column in this shallow lake with especially high biomasses (corresponding to up to $238 \mu \mathrm{g} \mathrm{C}^{-1}$ ) measured at 1.8 to $3.0 \mathrm{~m}$. In freshwater habitats, some Chlorobiaceae bacteria can grow in symbiotic associations with motile chemotrophic bacteria (Trüper \& Pfennig 1992, Glaeser \& Overmann 2004), but such cell aggregation was never seen during intensive microscopic examination of Mekkojärvi samples (K. Salonen pers. comm.).

Chlorobi are considered obligate photolithoautotrophs, even when utilizing organic acids such as acetate or pyruvate, showing a strict dependence upon a simultaneous supply of bicarbonate and sulfide or thiosulfate (Trüper \& Pfennig 1992) or ferrous iron (Heising et al. 1999). Early studies of GSB physiology (Hoare \& Gibson 1964) showed that in the process of photoassimilation, acetate is assimilated directly into the amino acids and not oxidized to carbon dioxide to generate reducing power for biosynthetic reactions leading to cell growth. Photoheterotrophy and polysaccharide storage within cells may indeed explain the relatively low difference between carbon dioxide fixation activities in light and dark (KuuppoLeinikki \& Salonen 1992) when considering the high biomass of GSB microscopically detected in Mekkojärvi (Kuuppo-Leinikki \& Salonen 1992) and re-examined in this study by molecular and fatty acid analysis.

Microbial interactions may also be significant during microbial transformations other than the sulfur cycle in natural ecosystems. Due to the high concentration of iron in the water column, iron oxidation-reduction reactions probably have an important role in the metaand hypolimnion of Mekkojärvi. Chlorobium ferrooxidans oxidizes ferrous iron. Sequences assigned to Fe(III)-reducing and acetate-oxidizing Geobacter psychrophilus were common in the anoxic hypolimnion, and sequences close to Rhodoferax ferrireducens were detected in all water layers except the oxic epilimnion. Sulfate- and Fe(III)-reducing organisms that can use acetate as an electron donor are of particular interest because of their possible role in outcompeting methanogens and thus inhibiting biogenic methane production (Schimel 2004). Among other chemolithotrophic bacteria, the iron-oxidizing Gallionella ferruginea was abundant in the upper and lower metalimnon. In the anoxic hypolimnion, sequences belonging to the phylum Planctomycetes were abundant, and this includes many facultative aerobic chemoorganotrophic species growing by fermentation or respiration, but also some strict anaerobic autotrophs that carry out the anaerobic oxidation of ammonia using nitrite (anammox; Strous et al. 1999). On the other hand, sequences of known aerobic ammonia-oxidizing bacteria were not detected in the Mekkojärvi clone libraries, although ammonium oxidation should be favored by the steep oxygen gradient and high ammonium concentration in the lower water layers.

Mekkojärvi has been the focus of numerous studies (e.g. Kankaala 1988, Taipale et al. 2008) confirming that high bacterial biomass is a typical feature of humic lakes when compared to phytoplankton primary production and biomass. Phagotrophic nanoflagellates were determined as major consumers of bacteria, daily clearing ca. $22 \%$ of the epilimnetic water column (Salonen \& Jokinen 1988), but direct grazing by cladocerans can also account for 3 to $48 \%$ of daily removal of the bacterial biomass (Kankaala 1988). However, grazing does not only happen in the oxic epilimnion, since diel vertical migration of zooplankton has been reported. Kuuppo-Leinikki \& Salonen (1992) noted that the maximum values of inorganic carbon uptake in Mekkojärvi were similar or sometimes even higher in the anaerobic hypolimnion (up to $90 \mathrm{mg} \mathrm{C} \mathrm{m}^{-3} \mathrm{~d}^{-1}$ ) than in the aerobic epilimnion during mid-summer stratification. Since the PLFAs assigned to the phytoplankton are low in the hypolimnion, this inorganic carbon uptake must be bacterial. The growth rate of Chlorobi has been considered slow (Manske et al. 2005); therefore, it is interesting that high abundance of GSB can be encountered between periods of water column overturn. In Mekkojärvi, the complete water overturn happens at least once per year, thus creating an unstable environment with fluctuating increases and complete die-off of anaerobic organisms, such as GSB. Decaying bacterial biomass would contribute reserves of labile carbon and nutrients for the use of heterotrophic bacterioplankton and consumers in the next period of stratification.

Further studies are needed to show whether GSB are highly abundant in other oxygen-stratified humic lakes and ponds, and what role they might have in the total carbon budget of these lakes. High autotrophic bacterial production (either chemo- or photoautotrophic) in the hypo- and metalimnion may shift the whole-year trophic status of those lakes towards theoretical net autotrophy, although the ultimate source of carbon dioxide for autotrophic bacteria as well as of methane for MOB is most likely derived from allochthonous carbon compounds. Efficient photoassimilation of acetate or other end products of anaerobic fermentation would also turn the net balance of the lake towards (photo)heterotrophy. Furthermore, it has been proposed that sulfate-reducing bacteria are important in outcompeting methanogens for substrates (acetate), thus inhibiting methane production (Schimel 2004). If photoassimilation of acetate by GSB is significant, GSB might also have the same crucial role as sulfate-reducing bacteria in the inhibition of acetoclastic methanogenesis. As in many forest lakes, methane production in 
Mekkojärvi is high, and the relatively low carbon stable isotope values of the methane $\left(\delta^{13} \mathrm{C},-77\right.$ to $-81 \%$, Kankaala et al. 2007) indicates hydrogenoclastic methane production from $\mathrm{H}_{2} / \mathrm{CO}_{2}$ (cf. Whiticar 1999). Indeed, the methane-producing groups in the Archaea clone library derived from the sediment of similar nearby lakes belonged mostly to Methanomicrobiales (Jurgens et al. 2000), which includes hydrogenoclastic methanogens. However, the extent and rate of acetate photoassimilation by Chlorobi remains largely speculative until it has been properly studied in situ under environmental conditions.

Acknowledgements. The study was supported by Academy of Finland grants 104438, 120089, and 105860. We thank the staff of Lammi Biological Station who contributed to field work, G. Eller for kindly providing the FISH results, and E. L. Porkka for helping with the laboratory analyses.

\section{LITERATURE CITED}

Alexander B, Andersen JH, Cox RP, Imhoff JF (2002) Phylogeny of green sulfur bacteria on the basis of gene sequences of $16 \mathrm{~S}$ rRNA and of the Fenna-Matthews-Olson protein. Arch Microbiol 178:131-140

Arvola L, Salonen K, Kankaala P, Lehtovaara A (1992) Vertical distributions of bacteria and algae in a steeply stratified humic lake under high grazing pressure from Daphnia longispina. Hydrobiologia 229:253-269

Balows A, Trüper HG, Dworkin M, Harder W, Schleifer K (eds) (1992) The prokaryotes - a handbook on the biology of bacteria: ecophysiology, isolation, identification, applications. Springer-Verlag, New York

> Bergström I, Heinänen A, Salonen K (1986) Comparison of acridine orange, acriflavine, and bisbenzimide stains for enumeration of bacteria in clear and humic waters. Appl Environ Microbiol 51:664-667

Bligh EG, Dyer WJ (1959) A rapid method of total lipid extraction and purification. Can J Biochem Physiol 37:911-917

Bowman JP, Skerratt JH, Nichols PD, Sly LI (1991) Phospholipid fatty-acid and lipopolysaccharide fatty-acid signature lipids in methane-utilizing bacteria. FEMS Microbiol Ecol 85:15-22

Burkert U, Warnecke F, Babenzien HD, Zwirnmann E, Pernthaler J (2003) Members of a readily enriched betaproteobacterial clade are common in surface waters of a humic lake. Appl Environ Microbiol 69:6550-6559

Canfield DE, Kristensen E, Thamdrup B (2005) Aquatic geomicrobiology. Adv Mar Biol 48. Elsevier Academic Press, San Diego, CA

Carpenter SR, Cole JJ, Pace ML, Van de Bogert M and others (2005) Ecosystem subsidies: terrestrial support of aquatic food webs from ${ }^{13} \mathrm{C}$ addition to contrasting lakes. Ecology $86: 2737-2750$

Eiler A, Langenheder S, Bertilsson S, Tranvik LJ (2003) Heterotrophic bacterial growth efficiency and community structure at different natural organic carbon concentrations. Appl Environ Microbiol 69:3701-3709

Eller G, Deines P, Grey J, Richnow HH, Kruger M (2005a) Methane cycling in lake sediments and its influence on chironomid larval partial derivative C-13. FEMS Microbiol Ecol 54:339-350
Eller G, Kanel LK, Krüger M (2005b) Cooccurrence of aerobic and anaerobic methane oxidation in the water column of Lake Plußsee. Appl Environ Microbiol 71:8925-8928

Findlay RH (1996) The use of phospholipid fatty acids to determine microbial community structure. In: Akkermans ADL, Elsas JD, Bruijn FJ (eds) Molecular microbial ecology manual. Kluwer Academic Publishers, Norwell, MA, p 4.1.4/1-17

Glaeser J, Overmann J (2004) Biogeography, evolution, and diversity of epibionts in phototrophic consortia. Appl Environ Microbiol 70:4821-4830

Glöckner FO, Zaichikov E, Belkova N, Denissova L, Pernthaler J, Pernthaler A, Amann R (2000) Comparative 16S rRNA analysis of lake bacterioplankton reveals globally distributed phylogenetic clusters including an abundant group of actinobacteria. Appl Environ Microbiol 66: 5053-5065

Griffiths RI, Whiteley AS, O'Donnell AG, Bailey MJ (2000) Rapid method for coextraction of DNA and RNA from natural environments for analysis of ribosomal DNA- and rRNA-based microbial community composition. Appl Environ Microbiol 66:5488-5491

> Grossart HP, Jezbera J, Hornák K, Hutalle KM, Buck U, Šimek K (2008) Top-down and bottom-up induced shifts in bacterial abundance, production and community composition in an experimentally divided humic lake. Environ Microbiol 10:635-652

Guckert JB, Ringelberg DB, White DC, Hanson RS, Bratina BJ (1991) Membrane fatty-acids as phenotypic markers in the polyphasic taxonomy of methylotrophs within the Proteobacteria. J Gen Microbiol 137:2631-2641

Hadas O, Pinkas R, Erez J (2001) High chemoautotrophic primary production in Lake Kinneret, Israel: a neglected link in the carbon cycle of the lake. Limnol Oceanogr 46:1968-1976

Hahn MW (2003) Isolation of strains to the cosmopolitan Polynucleobacter necessarius clusters from freshwater habitats located in three climatic zones. Appl Environ Microbiol 69:5248-5254

Heising S, Richter L, Ludwig W, Schink B (1999) Chlorobium ferrooxidans sp. nov., a phototrophic green sulfur bacterium that oxidizes ferrous iron in coculture with a 'Geospirillum' sp. strain. Arch Microbiol 172:116-124

Hoare DS, Gibson J (1964) Photoassimilation of acetate and the biosynthesis of amino acids by Chlorobium thiosulphatophilum. Biochem J 91:546-559

Imhoff JF (2003) Phylogenetic taxonomy of the family Chlorobiaceae on the basis of 16S rRNA and fmo (Fenna Matthews-Olson protein) gene sequences. Int J Syst Evol Microbiol 53:941-951

Jurgens G, Glöckner F, Amann R, Saano A, Montonen L, Likolammi M, Münster U (2000) Identification of novel Archaea in bacterioplankton of a boreal forest lake by phylogenetic analysis and fluorescent in situ hybridization. FEMS Microbiol Ecol 34:45-56

Kankaala P (1988) The relative importance of algae and bacteria as food for Daphnia longispina (Cladocera) in a polyhumic lake. Freshw Biol 19:285-296

> Kankaala P, Taipale S, Nykänen H, Jones RI (2007) Oxidation, efflux and isotopic fractionation of methane during autumnal turnover in a polyhumic, boreal lake. J Geophys Res 112, G02033, doi:10.1029/2006JG000336

> Keinänen MM, Korhonen LK, Martikainen PJ, Vartiainen T and others (2003) Gas chromatographic-mass spectrometric detection of 2- and 3-hydroxy fatty acids as methyl esters from soil, sediment and biofilm. J Chromatogr B 783:443-451 
Kenyon CN (1972) Fatty-acid composition of unicellular strains of blue-green-algae. J Bacteriol 109:827-834

Kuuppo-Leinikki P, Salonen K (1992) Bacterioplankton in a small polyhumic lake with an anoxic hypolimnion. Hydrobiologia 229:159-168

Lane DJ (1991) 16S/23S rRNA sequencing. In: Stackebrandt E, Goodfellow M (eds) Nucleic acid techniques in bacterial systematics. John Wiley \& Sons, Chichester, p 115-175

Macalady JL, Mack EE, Nelson DC, Scow KM (2000) Sediment microbial community structure and mercury methylation in mercury-polluted Clear Lake, California. Appl Environ Microbiol 66:1479-1488

Mancuso CA, Franzmann PD, Burton HR, Nichols PD (1990) Microbial community structure and biomass estimates of a methanogenic antarctic lake ecosystem as determined by phospholipid analyses. Microb Ecol 19:73-95

Manske AK, Glaeser J, Kuypers MM, Overmann J (2005) Physiology and phylogeny of green sulfur bacteria forming a monospecific phototrophic assemblage at a depth of 100 meters in the Black Sea. Appl Environ Microbiol 71: 8049-8060

McKenzie CM, Seviour EM, Schumann P, Maszenan AM and others (2006) Isolates of 'Candidatus Nostocoida limicola' Blackall et al. 2000 should be described as three novel species of the genus Tetrasphaera, as Tetrasphaera jenkinsii sp. nov., Tetrasphaera vanveenii sp. nov. and Tetrasphaera veronensis sp. nov. Int J Syst Evol Microbiol 56: 2279-2290

Moran MA, Hodson RE (1990) Bacterial production on humic and nonhumic components of dissolved organic carbon. Limnol Oceanogr 35:1744-1756

> Muyzer G, Dewaal EC, Uitterlinden AG (1993) Profiling of complex microbial-populations by denaturing gradient gel-electrophoresis analysis of polymerase chain reactionamplified genes coding for $16 \mathrm{~S}$ ribosomal-RNA. Appl Environ Microbiol 59:695-700

> Nichols PD, Guckert JB, White DC (1986) Determination of monounsaturated fatty-acid double-bond position and geometry for microbial monocultures and complex consortia by capillary GC-MS of their dimethyl disulfide adducts. J Microbiol Methods 5:49-55

O'Leary WM, Wilkinson SG (1988) Gram-positive bacteria. In: Ratledge C, Wilkinson SG (eds) Microbial lipids, Vol 1. Academic Press, London, p 188-202

> Percent SF, Frischer ME, Vescio PA, Duffy EB and others (2008) Bacterial community structure of acid-impacted lakes: What controls diversity? Appl Environ Microbiol 74: 1856-1868

Ratledge C, Wilkinson SG (eds) (1988) Microbial lipids, Vol 1. Academic Press, London

Salonen K (1979) A versatile method for the rapid and accurate determination of carbon by high temperature combustion. Limnol Oceanogr 23:337-348

Salonen K, Jokinen S (1988) Flagellate grazing on bacteria in a small dystrophic lake. Hydrobiologia 161:203-209

Schimel J (2004) Playing scales in the methane cycle: from microbial ecology to the globe. Proc Natl Acad Sci USA 101:12400-12401

Strous M, Fuerst JA, Kramer EHM, Logemann S and others (1999) Missing lithotroph identified as new planctomycete. Nature 400:446-449

Sundh I, Bastviken D, Tranvik LJ (2005) Abundance, activity, and community structure of pelagic methane-oxidizing bacteria in temperate lakes. Appl Environ Microbiol 71: 6746-6752

> Suzuki M, Rappe MS, Giovannoni SJ (1998) Kinetic bias in estimates of coastal picoplankton community structure obtained by measurements of small-subunit rRNA gene PCR amplicon length heterogeneity. Appl Environ Microbiol 64:4522-4529

Taipale S, Kankaala P, Jones RI (2007) Contributions of different organic carbon sources to Daphnia in the pelagic foodweb of a small polyhumic lake: results from mesocosm $\mathrm{DI}^{13} \mathrm{C}$-additions. Ecosystems 10:757-772

Taipale S, Kankaala P, Tiirola M, Jones RI (2008) Whole-lake dissolved inorganic ${ }^{13} \mathrm{C}$ additions reveal seasonal shifts in zooplankton diet. Ecology 89:463-474

Tiirola MA, Suvilampi JE, Kulomaa MS, Rintala JA (2003) Microbial diversity in a thermophilic aerobic biofilm process: analysis by length heterogeneity PCR (LH-PCR). Water Res 37:2259-2268

Tranvik LJ (1989) Bacterioplankton growth, grazing mortality and quantitative relationship to primary production. J Plankton Res 11:985-1000

Trüper HG, Pfennig N (1992) The family Chlorobiaceae. In: Balows A, Trüper HG, Dworkin M, Harder W, Schleifer $\mathrm{KH}$ (eds) The prokaryotes - a handbook on the biology of bacteria: ecophysiology, isolation. Springer-Verlag, New York, p 3583-3592

- Tulonen T (1993) Bacterial production in a mesohumic lake estimated from [14C]leucine incorporation rate. Microb Ecol 26:201-217

Urbach E, Vergin KL, Young L, Morse A, Larson GL, Giovannoni SJ (2001) Unusual bacterioplankton community structure in ultra-oligotrophic Crater Lake. Limnol Oceanogr 46:557-572

- Van der Gucht K, Vandekerckhove T, Vloemans N, Cousin $\mathrm{S}$ and others (2005) Characterization of bacterial communities in four freshwater lakes differing in nutrient load and food web structure. FEMS Microbiol Ecol 53: 205-220

Vannini C, Pockl M, Petroni G, Wu QL and others (2007) Endosymbiosis in statu nascendi: close phylogenetic relationship between obligately endosymbiotic and obligately free-living Polynucleobacter strains (Betaproteobacteria). Environ Microbiol 9:347-359

Vila X, Abella CA, Figueras JB, Hurley JP (1998) Vertical models of phototrophic bacterial distribution in the metalimnetic microbial communities of several freshwater North American kettle lakes. FEMS Microbiol Ecol 25: 287-299

- Virtue P, Nichols PD, Boon PI (1996) Simultaneous estimation of microbial phospholipid fatty acids and diether lipids by capillary gas chromatography. J Microbiol Methods 25: $177-185$

Von Wintzingerode F, Göbel UB, Stackebrandt E (1997) Determination of microbial diversity in environmental samples: pitfalls of PCR-based rRNA analysis. FEMS Microbiol Rev 21:213-229

- Warnecke F, Amann R, Pernthaler J (2004) Actinobacterial 16S rRNA genes from freshwater habitats cluster in four distinct lineages. Environ Microbiol 6:242-253

Wartiainen I, Hestnes AG, McDonald IR, Svenning MM (2006) Methylobacter tundripaludum sp. nov., a methaneoxidizing bacterium from Arctic wetland soil on the Svalbard islands, Norway (78 degrees N). Int J Syst Evol Microbiol 56:109-113

- White DC, Davis WM, Nickels JS, King JD, Bobbie RJ (1979) Determination of the sedimentary microbial biomass by extractable lipid phosphate. Oecologia 40:51-62

- Whiticar MJ (1999) Carbon and hydrogen isotope systematics of bacterial formation and oxidation of methane. Chem Geol 161:291-314

Wieser M, Denner EBM, Kämpfer P, Schumann P and oth- 
ers (2002) Emended descriptions of the genus Micrococcus, Micrococcus luteus (Cohn 1872) and Micrococcus lylae (Kloos et al. 1974). Int J Syst Evol Microbiol 52: 629-637

Wilson K (1990) Preparation of genomic DNA from bacteria. In: Ausubel FM, Brent R, Kingston RE, Moore DD and

Editorial responsibility: Klaus Jürgens,

Rostock, Germany others (eds) Current protocols in molecular biology. Wiley, New York, p 2.4.1-2.4.2

Zwart G, Crump BC, Kamst-van Agterveld MP, Hagen F, Han SK (2002) Typical freshwater bacteria: an analysis of available 16S rRNA gene sequences from plankton of lakes and rivers. Aquat Microb Ecol 28:141-155

Submitted: April 21, 2008; Accepted: December 29, 2008

Proofs received from author(s): February 24, 2009 